\title{
Pengembangan LKPD Berbasis Problem Based Learning untuk Meningkatkan Berpikir Kritis Peserta Didik pada KD Perdagangan Internasional
}

\author{
Eni Ismawati \\ Program Studi Pendidikan Ekonomi, Fakultas Ekonomi, Universitas Negeri Surabaya \\ e-mail: eniismawati@mhs.unesa.ac.id \\ Muhammad Abdul Ghofur \\ Program Studi Pendidikan Ekonomi, Fakultas Ekonomi, Universitas Negeri Surabaya \\ e-mail: Muhammadghofur@unesa.ac.id
}

\begin{abstract}
Abstrak
Dari observasi yang dilaksanakan berpikir kritis peserta didik SMAN 1 Sidayu belum maksimal. Dimana peserta didik belum dapat mempertanggungjawabkan sumber jawaban yang mana merupakan salah satu indikator berpikir kritis. Selain itu guru juga tidak memakai LKPD sebagai bahan ajar di sekolah. Penelitian ini memiliki tujuan untuk mengembangkan LKPD serta menganalisis respon peserta didik dan efektifitas penggunaannya LKPD sebagai salah satu perangkat pembelajaran. Jenis penelitian yang digunakan pada penelitian ini yakni penelitian dan pengembangan (R\&D) menggunakan model 4-D yang terdiri dari define, desain, development, dan disseminate. Pengumpulan data didapatkan dari hasil validasi kelayakan, pretest dan posttest, serta respon peserta didik. Hasil analisis yang sudah dilakukan materi dalam LKPD dinyatakan layak begitu pula dengan kelayakan kegrafikan dan kelayakan bahasa. Berdasarkan angket respons siswa, tingkat respons yang didapat adalah sebesar $81 \%$. Berdasarkan hasil uji coba siswa yang mencapai ketuntasan belajar naik menjadi $76 \%$ dengan hasil N-Gain sebesar 0,7 . Hal tersebut memperlihatkan bahwa pengembangan LKPD berbasis Problem Based Learning pada Kompetensi Dasar Perdagangan Internasional dapat meningkatkan berpikir kritis dan layak digunakan.
\end{abstract}

Kata Kunci: Lembar Kegiatan Peserta Didik, Problem Based Learning, Berpikir Kritis.

\begin{abstract}
From the observation that performed critical thinking of students SMAN 1 Sidayu is not maximized. Where learners are not able to account for the answer source which is one of the critical thinking indicators. In addition, the teachers did not use LKPD as a teaching material in schools. This study aims to develop LKPD and analyse student responses and the effectiveness of using LKPD as a learning tool. The type of research used in this study is research and development (R\&D) using a 4-D model consisting of define, design, development, and disseminate. Data collection was obtained from the results of validation of eligibility, pretest and posttest, and students' responses. The results of the analysis that have been done by the material in LKPD are declared to be feasible as well as the feasibility of graphic and language feasibility. Based on the student response questionnaire, the response rate obtained was $81 \%$. Based on the results of student trials reaching mastery learning rose to $76 \%$ with an $\mathrm{N}$-Gain result of 0.7 . This shows that the development of LKPD based on Problem Based Learning in Basic International Trade Competencies can improve critical thinking and is appropriate for use.
\end{abstract}

Keywords: Student Activity Sheet, Problem Based Learning, Critical Thinking.

\section{PENDAHULUAN}

Dalam kehidupan manusia terdapat banyak aspek yang dapat mempengaruhi kemajuan manusia, salah satunya yaitu pendidikan. Pendidikan bisa menciptakan sumber daya manusia yang memiliki kualitas. Salah satu tujuan dari pendidikan yaitu menjadikan peserta didik untuk bisa memperluas dan menerapkan ilmu pengetahuan di sekolah maupun di masyarakat. Dalam UU No. 20 tahun 2003 pendidikan merupakan suatu cara yang dilaksanakan dengan sadar dan siap untuk menciptakan kondisi belajar dan proses belajar supaya peserta didik bisa aktif dalam mengembangkan kemampuannya dan mempunyai sikap spiritual, membentuk kepribadian, kendali diri, kecerdasan, akhlak juga keterampilan yang dibutuhkan oleh diri sendiri,masyarakat, bangsa dan Negara. Saat ini kurikulum yang digunakan di Indonesia yakni kurikulum 2013 (K-13) revisi 2017. K-13 revisi 2017 merupakan penyempurnaan dari K-13. Pada Lampiran Permendikbud No. 69 dan N. 20 Tahun 2013 didalamnya menyatakan bahwa pada kurikulum 2013 peserta didik dipaksa untuk berperan aktif saat kegiatan pembelajaran dan tidak boleh pasif dengan mendengarkan guru. Selain berperan aktif 
Pengembangan LKPD Berbasis Problem Based Learning ...

dalam pembelajaran peserta didik juga dituntut agar dapat berfikir kritis.

Dibidang akademik berpikir kritis peserta didik sangatlah penting DeAngelo et al., (dalam Huber \& Kuncel, 2016). Pada saat kegiatan belajar peserta didik akan mendapatkan beberapa materi yang diberikan oleh guru dimana peserta didik harus memahami materi tesebut. Untuk bisa menumbuhkan keterampilan berpikir kritis, guru haruslah memberikan rangsangan pada peserta didik dan peserta didik memberikan respon dari rangsangan yang diberikan guru. Di SMAN 1 Sidayu Gresik keterampilan berpikir kitis peserta didik belum tercapai secara maksimal. Peserta didik belum bisa mencapai indikator berpikir kritis yakni membangun keterampilan dasar dimana peserta didik belum bisa mempertanggungjawabkan sumber jawaban yang diperoleh bisa dipercaya ataukah tidak. Hal tersebut diketahui dari hasil wawancara terhadap guru mata pelajaran ekonomi disekolah tersebut.

Salah satu jalan keluar yang bisa dipakai untuk meningkatkan berpikir kritis adalah dengan menggunakan model pembelajaran Problem Based Learning (PBL). dalam kurikulum 2013 Menurut Esema, Susari, \& Daniel (2012) PBL merupakan pendekatan dalam pembelajaran yang memanfaatkan permasalahan di kehidupan nyata yang bertujuan untuk berlatih berpikir kritis, mencari solusi suatu persoalan dan mendapatkan informasi dari materi pelajaran. Sedangkan menurut Setyorini, Sukiswo, \& Subali, (2011) dalam kegiatan belajar mengajar PBL ditandai dengan pemberian masalah yang harus dikerjakan oleh peserta didik secara berkelompok untuk memecahkan masalah dan dari hal tersebut nantinya dapat meningkatkan kemampuan berpikir kritis. Sejalan dengan pendapat Trianto (2015) pembelajaran berdasarkan masalah merupakan suatu pendekatan yang efektif untuk pembelajaran yang berhubungan dengan proses berpikir tingkat tinggi. Jadi dalam model pembelajaran PBL yang mana siswa memiliki peran aktif juga diarahkan untuk memecahkan persoalan yang telah diberikan yang nantinya dapat meningkatkan kemampuan berpikir kritis peserta didik. Berdasarkan hasil wawancara yang dilakukan Di SMAN 1 Sidayu Gresik pada saat kegiatan pembelajaran model pembelajaran PBL jarang digunakan. Guru kerap kali menerapkan metode ceramah serta diskusi sesuai dengan materi yang diajarkan pada saat pembelajaran. Untuk metode diskusi biasanya menggunakan model pembelajaran kooperatif. Model pembelajaran kooperatif masih belum maksimal untuk meningkatkan berpikir kritis karena dalam model tersebut bertujuan untuk dapat mendorong peserta didik dalam bekerja sama.

Di SMAN 1 Sidayu Gresik juga tidak menggunakan bahan ajar LKPD dalam kegiatan pembelajaran, bahan ajar yang digunakan yaitu buku paket dan power point. selain itu guru pada saat pembelajaran akan memberikan soal-soal baik secara lisan maupun tertulis yang wajib dijawab oleh peserta didik baik secara perorangan maupun kelompok. Soal- soal tersebut akan diberikan kepada peserta didik setelah guru menjelaskan materi yang telah dipelajari. Hasil dari soal tersebut dijadikan guru sebagai acuan tingkat pemahaman peserta didik terhadap materi yang sudah dipelajari. Soal-soal yang diberikan belum dapat memacu peserta didik untuk berpikir kritis karena pertanyaan yang diberikan kurang bersifat analisis. Menurut Prastowo (2015) LKPD memiliki fungsi sebagai bahan ajar yang bisa mengurangi peran guru serta menjadikan peserta didik untuk aktif dalam pembelajaran, selain itu juga mememberikan kemudahan peserta didik dalam menguasai materi yang diajarkan, sebagai bahan ajar yang sederhana dan banyak akan tugas dijadikan sebagai latihan, serta mempermudah dalam menyampaikan materi kepada peserta didik.

Materi yang dipakai pada penelitian ini yaitu perdagangan internasional. Pada materi tersebut cocok untuk dikembangkan pada soal-soal yang bersifat analisis karena terdapat banyak istilah yang sulit dipahami peserta didik, seperti istilah dalam kebijakan perdagangan internasional. Selain itu di Indonesia sering terjadi kegiatan ekspor impor yang merupakan salah satu kegiatan perdagangan internasional sehingga terdapat banyak kasus yang dapat dianalisis oleh peserta didik agar peserta didik bisa menerapkan pengetahuan yang dimilikinya dengan begitu materi yang didapatkan akan mudah diserap.

Lembar Kegiatan Peserta Didik merupakan lembar kertas yang dicetak yang berisikan ringkasan materi, tugas, tahap dan penunjuk pengerjaannya yang bertujuan untuk mencapai KD yang akan dipelajari. Sejalan dengan pemikiran Prastowo (2015, p. 204) LKPD adalah jenis bahan ajar cetak yang berisikan ringkasan materi, penunjuk penggunaan, serta tugas yang wajib dikerjakan oleh peserta didik sesuai dengan KD.

Menurut Trianto (2015, p. 64) model problem based learning dimulai dengan memberikan permasalahan pada kehidupan nyata yang berfungsi untuk menyelesaikan masalah tersebut, dalam menyelesaikan masalahnya membutuhkan kerjasama antar siswa dan guru bertugas untuk memandu siswa agar sinkron dengan tahapan problem based learning. Dari penerapan PBL dalam pembelajaran diharapkan berpikir kritis peserta didik dapat meningkat karena peserta didik dilatih untuk menyelesaikan persoalan yang biasanya ditemui pada keseharian. 
Tabel 1.1 Tahapan Problem Based Learning

\begin{tabular}{|l|}
\hline \multicolumn{1}{|c|}{ Tahapan } \\
\hline Mengarahkan siswa pada masalah \\
\hline Mempersiapkan siswa untuk belajar \\
\hline $\begin{array}{l}\text { Membantu penelitian secara mandiri maupun } \\
\text { kelompok }\end{array}$ \\
\hline Mengembangkan dan menyajikan hasil karya \\
\hline $\begin{array}{l}\text { Menganalisis dan mengevaluasi proses pemecahan } \\
\text { masalah }\end{array}$ \\
\hline
\end{tabular}

Sumber: (Arends, 2013)

Menurut Dwijananti \& Yulianti (2010) berpikir kritis adalah kegiatan analisis, identifikasi serta mengkaji ide atau pandangan secara rinci dan jangkap yang didapatkan dari observasi dan pengetahuan. Sejalan dengan Amri (2015, p. 149) berpikir kritis merupakan kegiatan berpikir yang berkaitan dengan penggunaan logika. Sehingga bisa disimpulkan yakni berpikir kritis merupakan kegiatan identifikasi suatu pengetahuan dengan menggunakan logika.

Tabel 1.2 Indikator Berpikir Kritis

\begin{tabular}{|l|}
\hline \multicolumn{1}{|c|}{ Indikator } \\
\hline Memberikan penjelasan sederhana \\
\hline Membangun keterampilan dasar \\
\hline Menyimpulkan \\
\hline Memberikan penjelasan lanjut \\
\hline Mengatur strategi dan taktik \\
\hline
\end{tabular}

Sumber: (Rahayu \& Amalia, 2019)

Penelitian ini memiliki tujuan untuk menganalisis kelayakan LKPD untuk meningkatkan berpikir krits, respon peserta didik terhadap LKPD, dan efektifitas LKPD berbasis PBL sebagai bahan ajar yang dikembangkan.

\section{METODE}

Jenis penelitian yang dipakai adalah Research and Development (R\&D) yang mana penelitian R\&D tersebut merupakan penelitian yang dipakai guna menciptakan suatu produk tertentu, dan meguji efektifitas suatu produk yang telah dibuat (Sugiyono, 2015). Model penelitian yang dipakai yaitu 4D berdasarkan saran Thiagarajan, Sammel, \& Sammel yang memiliki 4 tahap yakni Define (pendefinisian), Design (perancangan), Develop (pengembangan), dan Disseminate (penyebaran). Untuk tahap Disseminate (penyebaran) hanya terbatas pada kelas lain.

Berikut merupakan gambaran tahap-tahap dari penelitian pengembangan 4D.

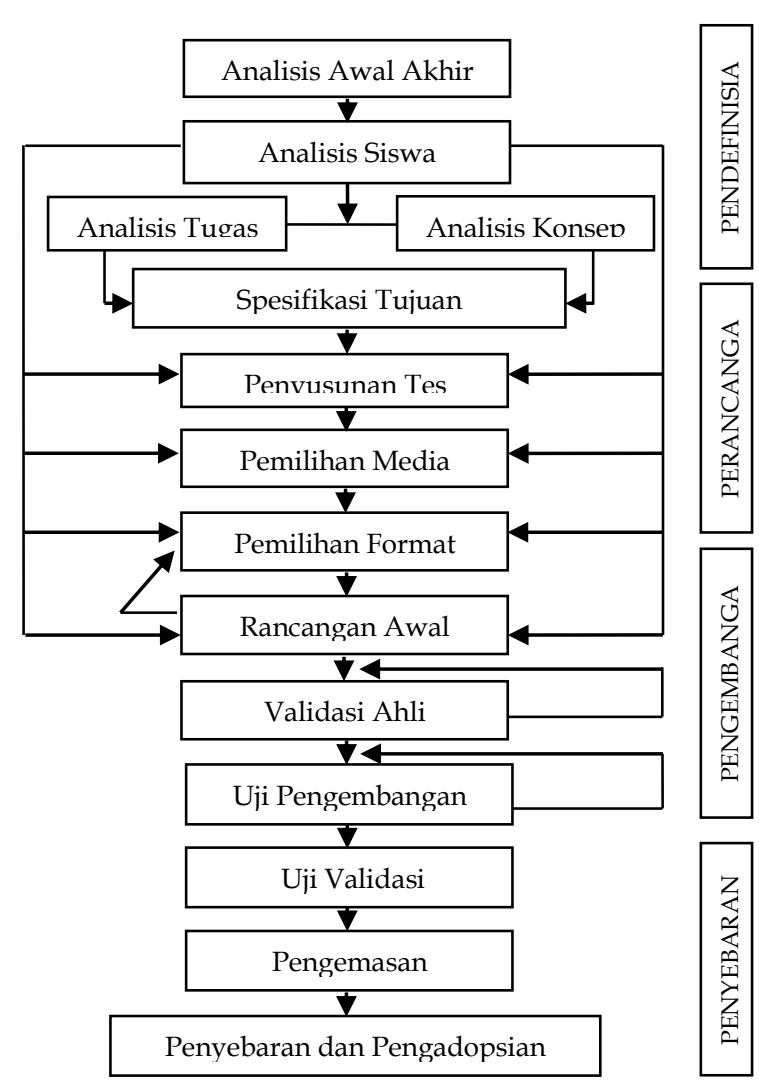

\section{Gambar 1.1 Tahap Penelitian dan \\ Pengembangan Model 4D}

Sumber : Diadaptasi dari Thiagarajan, Sammel dan Sammel (1974)

Dari gambar diatas diketahui bahwa penelitian 4D dibagi menjadi 4 tahap yakni pertama pendefinisian (defne) adalah tahap pokok dalam penelitian yang terdiri dari 5 tahapan yaitu (a) analisis ujung depan, (b) analisis peserta didik, (c) analisis tugas, (d) analisis konsep, (e) analisis tujuan pembelajaran. Tahap kedua yaitu perancangan (design) bertujuan untuk menyiapkan desain perangkat pembelajaran terdiri dari 3 langkah (a) penyusunan tes, (b) pemilihn media, (c) pemilihan format. Tahap ketiga yakni pengembangan (develop) bertujuan untuk menghasilkan LKPD sesuai dengan masukan para ahli yang dibagi menjadi 4 tahap (a) perencanaan awal, (b) validasi draf, (c) simulasi, (d) uji coba. Untuk tahap terakhir yakni penyebaran (disseminate) dimana LKPD yang telah dikembangkna akan disebarluaskan.

Subjek uji coba yang digunakan yaitu peserta didik kelas XI Mipa 7 SMAN 1 Sidayu dengan jumlah 35 anak. Desain uji coba yang dipakai yakni One Group PretestPosttest Design (Sugiyono, 2015) yang digambarkan dibawah ini:

$$
\mathrm{O}_{1}-\mathrm{X}-\mathrm{O}_{2}
$$

\section{Gambar 1.2 Desain Uji Coba}

Sumber: (Sugiyono, 2015)

Keterangan:

$\mathbf{O}_{1}$ : Pretest sebelum perlakuan

$\mathrm{X}$ : perlakuan

$\mathbf{O}_{2}$ : posttest sesudah perlakuan 
One Group Pretest-Posttest Design dimulai dengan memberikan pretest lebih dulu sebelum memberikan tindakan. Sesudah diberikan tidakan, n soal posttest akan diserahkan kepeserta didik. Hal tersebut dilakukan untuk melihat adanya peningkatan belajar atau tidak.

Instrument pada penelitian ini yaitu (1) telaah dan validasi materi, bahasa, grafik dan evaluasi yang dilakukan oleh para ahli, (2) angket respon peserta didik terhadap LKPD, (3) soal pretest posttest untuk mengetahui keefektivitasan LKPD.

Teknik analisis data yang pakai pada lembar telaah dan validasi menggunakan skala likert dijadikan sebagai pengukur kelayakan LKPD, untuk angket respon peserta didik menggunakan skala guttman yang kelayakannya menggunkan skal likert, dan selanjutnya peningkatan berpikir kritis peserta didik diukur menggunakan $\mathrm{N}$-Gain.

\section{HASIL DAN PEMBAHASAN Hasil}

Penelitan ini akan menghasilkan LKPD berbasis PBL bertujuan meningkatkan berpikir kritis yang menggunakan model 4D. pada tahap awal yakni pendefinisian (define): (a) analisis ujung depan dimana SMAN 1 Sidayu dalam pembelajaran dikelas XI MIPA 7 menggunakan bahan ajar berupa lembarsoal yang bersifat spontanitas yaitu soal-soal yang diberikan bisa berupa cetak maupun lisan, tetapi lembar tersebut masih belum bisa menolong peserta didik untuk memahami materi juga melatih berpikir kritis. Oleh karena itu penelitian ini mengembangkan LKPD dengan basis PBL untuk melatih berpikir kritis peserta didik, (b) analisis peserta didik menggunakan kelas XI Mipa SMAN 1Sidayu sebanyak 35 anak, (c) analisis tugas peserta didik akan mengerjakan soal pretest sebelum pembelajaran, pada saat pembelajaran peserta didik akan mengerjakan studi kasus yang ada pada LKPD, dan selanjutnya akan mengerjakan soal posttest, (d) analisis konsep yaitu menggunakan KD perdagangan internasional, (e) analisis tujuan pembelajaran disesuaikan dengan $\mathrm{KD}$ juga indikator perdagangan internasional.

Tahap kedua yakni perancangan (design). Dalam tahap ini isi LKPD dicocokkan dengan tahapan PBL yakni di dalam LKPD terdapat persoalan berupa artikel yang harus dipecahkan oleh peserta didik serta soal-soal yang mencakup indikator berpikir kritis sehingga bisa mendorong berpikir kritis peserta didik. desain menggunankan warna yang menarik sehingga bisa menarik minat peserta didik dalam menggunakannya. Ukuran dari LKPD yakni menggunkan kertas A4 $(21 \mathrm{~cm}$ $\mathrm{x} 29,7 \mathrm{~cm})$.

Tahap ketiga ialah pengembangan (develop) untuk tahapan ini daraf yang telah disusun nantinya di telaaah oleh para ahli dan akan direvisi. Setelah direvisi draf LKPD akan divalidasi terlebih dahulu sebelum diujicobakan pada peserta didik. sebelum pembelajaran berlangsung soal pretest lebih dulu akan disebarkan pada peserta didik kemudian saat pembelajaran berlanngsung penggunaan LKPD akan diterapkan. Setelah itu akan diberikan soal posttest.
Tahap terakhir adalah penyebaran (disseminate) yang pada penelitian ini hanya di sebarkan pada kelas lain.

\section{Pembahasan \\ Kelayakan Lembar Kegiatan Peserta Didik}

Kelayakan LKPD berbasis PBL pada KD perdagangan internasional dinilai dari validasi yang sudah dilaksanakan oleh para ahli yaitu ahli materi, grafik, bahasa dan evaluasi.

Validasi materi dijadikan sebagai penilaian materi yang ada pada LKPD. Berdasarkan dari hasil perhitungan validasi ahli materi terdapat beberapa komponen yang dinilai yakni cakupan materi, kemutakhiran dan kontekstual, ketaatan pada hokum serta perundangundangan, cakupan keterampilan, teknik penyajian, serta pendukung penyajian. Berdasarkan ahli materi LKPD yang dikembangkan memperoleh nilai $81 \%$ berkategori "Sangat Layak". Sejalan dengan riset yang dilaksanakan oleh (Aini, Syachruroji, \& Hendracipta, 2019) LKPD yang dikembangkan divalidasi oleh dua validator ahli materi didapatkan nilai sebesar $95,6 \%$ berkategori "sangat baik".

Validasi grafik digunakan utuk menilai desain dan tata letak LKPD. Dari hasil validasi ahli grafik terdapat empat komponen yang dinilai yakni: ukuran dari LKPD, desain kulit LKPD, tipografi cover buku, dan desain isi LKPD. Dri keempat komponen tersebut menurut ahli grafik LKPD yang dikembangkan sudah sesuai sehingga memperoleh nilai 100\% dengan kategori "Sangat Layak". Sesuai dengan riset yang sudah dilaksanakan oleh (Aisyah \& Suci, 2018) LKPD yang telah divalidasi oleh ahli grafis memperoleh nilai $80,8 \%$ dengan kategori "Sangat Sesuai".

Validasi bahasa digunakan untuk menilai kebahasaan pada LKPD. Validasi bahasa terdapat empat komponen yakni: kelayakan kebahasaan, kemampuan memotivasi, kelugasan serta penggunaan istilah dan symbol. Dari empat komponen tersebut diperoleh nilai $91 \%$ dengan kategori "Sangat Layak". Sesuai dengan penelitian (Warti \& Hurriyah, 2019) LKPD yang dikembangkan memperoleh hasil validasi kebahasaan sebesar $88,8 \%$.

Yang terakhir yaitu validasi evaluasi yang digunakan untuk menilai soal-soal dalam LKPD apakah telah cocok dengan indikator berpikir kritis ataukah belum. Validasi evaluasi terdapat enam komponen yakni: penyusunan kisi-kisi instrument test, memberikan penjelasan sederhana, membangun keterampilan dasar, menyimpulkan, memberikan penjelasan lebih lanjut, dan mengatur strategi dan taktik. LKPD yang dikembangkan memperoleh nilai sebesar 76\% dengan kategori "Layak".

Berdasarkan hasil validasi yang dikerjakan oleh empat ahli diatas LKPD yang dikembangkan layak dijadikan sebagain bahan ajar pada saat pembelajaran ekonomi. 


\section{Respon Peserta Didik terhadap Lembar Kegiatan} Peserta Didik berbasis Problem Based Learning

Berdasarkan hasil rekapitulasi respon peserta didik didapatkan nilai sebanyak $81 \%$ termasuk dalam kategori "Sangat Layak" Terdapat dua kelayakan yang mimiliki nilai kurang maksimal yakni kelayakan materi sebesar $79 \%$ dan kelayakan grafis dengan nilai $80 \%$. Hal tersebut dikarenakan menurut peserta didik materi LKPD sulit serta warna yang ada pada LKPD menurut peserta didik masih kurang menarik.Sejalan dengan riset yang dilaksanakan oleh (Fithriyah \& Wiwik, 2018) yang mengembangkan LKPD berbasis PBL mendapatkan nilai $81.15 \%$ dengan kategori "sangat baik".

\section{Analisis Efektifitas Penggunaan LKPD terhadap Peningkatan Berpikir Kritis Peserta Didik}

Dalam pengukuran peningkatan berpikir kritis peserta didik dapat diketahui dari hasil nilai dari adanya soal pretest dan posttest baik sebelum penerapan LKPD maupun setelah adanya penerapan LKPD. Soal pretest dan posttest menggunakan kriteria soal $\mathrm{C} 4$. Nilai peserta didik dinyatakan tuntas apabila mendapatkan nilai $\geq 75$. Hasil dari pretest menunjukkan ketuntasan yang diperoleh sebesar $6 \%$ dari 35 peserta didik. sedangkan 94\% Dinyatakan tidak tuntas. Pada nilai posttest diperoleh prosentase ketuntasan sebesar $76 \%$ dan $24 \%$ dinyatakan tidak tuntas yang berasal dari 35 peserta didik.

Berdasarkan hasil dari pengerjaan pretest juga posttest yang sudak dilaksanakan kelas XI MIPA 7 SMAN 1 Sidayu terdapat adanya peningkatan dimana pada hasil pretest memperoleh hasil ketuntasan sebesar $6 \%$ naik menjadi $76 \%$ pada hasil posttest. Kemudian hasil tersebut dianalisis dengan menggunakan n-gain didapatkan nilai 0,7 termasuk pada kategori "Sedang" sehingga LKPD yang dikembangkan bisa meningkatkan berpikir kritis peserta didik. Sesuai dengan riset (Astuti, Danial, \& Anwar, 2018) yang mengatakan bahwa dengan LKPD berbasis PBL berpikir kritis bisa meningkat. Selain itu diperkuat juga oleh riset yang dilaksanakan (Rahmawati, Roektiningrum, \& Maryanto, 2017) yang mengembangkan LKPD berbasis PBL dengan hasil berpikir kritis bisa meningkat.

\section{PENUTUP}

\section{Simpulan}

Berdasarkan hasil dari penelitian pengembangan LKPD berbasi PBL pada kompetensi dasar perdagangan internasional dapat disimpulkan sebagai berikut, (1) dari hasil validasi yang telah dikerjakan oleh ahli materi materi, grafis, bahasa serta evaluasi LKPD yang dikembangkan layak dipakai pada saat kegiatan belajar, (2) dari angket respon yang telah disebar pada peserta didik kelas XI MIPA 7 mendapatkan hasil sebanyak $81 \%$ termasuk kategori "Sangat Layak" yang memperlihatkan bahwa dari LKPD yang dikembangkan baik isi, penyajian, bahasa, maupun kegrafikan layak untuk digunakan, (3) hasil pretest dan posttest LKPD yang dikembangkan dapat meningkatkan berpikir kritis peserta didik dengan nilai n-gain sebanyak 0,7 dengan kategori "Sedang".

\section{Saran}

Produk LKPD berbasis PBL disarankan dapat dikembangkan dan disempurnakan lagi. Uji coba di kalangan yang lebih luas perlu dilakukan dengan metode yang lebih kompleks untuk mendapat masukan yang legih banyak.

\section{DAFTAR PUSTAKA}

Aini, N. A., Syachruroji, A., \& Hendracipta, N. 2019. Pengembangan LKPD Berbasis Problem Based Learning Pada Mata Pelajaran IPA Materi Gaya. Jurnal Pendidikan Dasar, 10 (1).

Aisyah, L., \& Suci, R. 2018. Pengembangan Lembar Kegiatan Peserta Didik (LKPD) Akuntansi Perusahaan Dagang Berbasis Problem Based Learning Pada Kelas XI Akuntansi Di SMK Negeri 1 Surabaya. Jurnal Pendidikan Akuntansi, Vol 6 (1).

Amri, S. 2015. Implementasi Pembelajaran Aktif Dalam Kurikulum 2013. Jakarta: Prestasi Pustaka Jakarta.

Astuti, S., Danial, M., \& Anwar, M. 2018. Pengembangan LKPD Berbasis PBL (roblem based learning) Uuntu Meningkatkan Keterampilan Bberpikir Kritis Peserta Didik Pada Materi Kesetimbangan Kimia. Journal Chemistry Education Review, Vol. 1 (2).

Dwijananti, P., \& Yulianti, D. 2010. Pengembangan Kemampuan Berpikir Kritis Mahasiswa Melalui Pembelajaran Pproblem Based Iinstruction Pada Mata Kuliah Fisika Lingkungan. Jurnal Pendidikan Fisika Indonesia.

Esema, D., Susari, E., \& Daniel, K. 2012. Problem Based Learning, Vol 28 (2).

Fithriyah, L., \& Wiwik, S. U. 2018. Pengembangan lkpd Berbasis Problem Based Learning Untuk Meningkatkan Kemampuan Berpikir Kreatif Siswa SMA Pada Pembelajaran Geografi Kelas XI IPS. Jurnal Pendidikan Geografi, Vol 5 (9).

Huber, C. R., \& Kuncel, N. R. 2016. Does College Teach Critical Thinking? A Meta-Analysis. Journal Review of Educational Research, Vol. 86 (2.

Prastowo, A. 2015. Panduan Kreatif Membuat Bahan Ajar Inovatif. Jogjakarta: DIVA Press.

Rahmawati, S., Roektiningrum, E., \& Maryanto, A. 2017. Pengembangan LKPD IPA Berbasis Problem Based Learning Tema Pemanasan Global Untuk 
Meningkatkan Keterampilan Berpikir Kritis Peserta DdidikSMP/MTs. Pendidikan Matematika Dan Sains, Vol. 6 (5).

Setyorini, U., Sukiswo, S. E., \& Subali, B. 2011. Penerapan Model Problem Based Learning Untuk Meningkatkan Kemampuan Berpikir Kritis Siswa SMA. Jurnal Pendidikan Fisika Indonesia.

Sugiyono. 2015. Metode Penelitian Pendidikan (Pendekatan Kuantitatif, Kualitatif, dan R\&D). Bandung: CV Alfabeta.

Trianto. 2015. Mendesain Model Pembelajaran Inovatif, Progresif, dan Kontekstual. Jakarta: Prenadamedia Group.

Warti, Y., \& Hurriyah. 2019. Pengembangan LKPD Berbasis Problem Based Learning Pada Materi Gelombang Elektromagnetik Untuk Peserta Didik Kelas X SMA/MA. Natural Science Journal, 5 (1). 